DOI: https://doi.org/10.32836/2521-666X/2020-68-3

УДК 339.13.339.92(477)

Губарь О.В.

кандидат економічних наук, доцент,

доцент кафедри економічної теорії та підприємництва,

Національний університет «Запорізька політехніка»

\title{
Gubar Olena
}

Zaporizhzhia Polytechnic National University

\section{ВПЛИВ ГЛОБАЛІЗАЦІЇ ТА РЕГІОНАЛІЗАЦІЇ НА РОЗВИТОК НАЦІОНАЛЬНОЇ ЕКОНОМІКИ УКРАЇНИ}

\section{INFLUENCE OF GLOBALIZATION AND REGIONALIZATION ON THE DEVELOPMENT OF THE NATIONAL ECONOMY OF UKRAINE}

\begin{abstract}
У статті розкрито сутнісні характеристики глобалізації та регіоналізаиії, ӥх суперечливий взаємозв'язок. Проаналізовано вплив сучасних глобалізаційних процесів та європейської регіоналізації на національну економіку Украӥни. Здійснено аналіз місия України у світовому господарстві, ї̈ рівня глобалізації, транснаціоналізаиї та залученості в міжнародну торгівлю. Розкрито вплив європейської інтегращії України на основі результатів Угоди про асоиіацію України та ЄС за 2013-2019 рр. у таких аспектах, як: інституційний вплив; потік інвестицій в Украйну з СС; зміни у зовнішній торгівлі Украӥни та ї̈ регіонів; вплив на малий та середній бізнес; вплив розвитку економіки ЄС на обсяги українського експорту до ЄС. Обтрунтовано напрями диверсифікаиії регіональної інтеграції. Акцентовано на необхідності розроблення довготермінової програми співробітництва Украӥни з краӥнами Південно-Східної Азї̈ з визначенням пріоритетів співробітнищтва. Запропоновано заходи щцодо розвитку регіонального співробітництвв з Китаєм, які полягають у вступі Украӥни до Азіатського банку інфраструктурних проектів та формуванні чіткого інвестиційного портфоліо.
\end{abstract}

Ключові слова: глобалізація, регіоналізаџія, глобальна регіоналізаџія, національна економіка, європейська інтеграція, диверсифікаиія міжнародного співробітнищтва.

В статье раскрыты сущзностные характеристики глобализащии и регионализащии, их противоречивая взаимосвязь. Проанализировано влияние современных глобализационных процессов и европейской регионализации на национальную экономику Украины. Проанализированы роль Украины в мировом хозяйстве, уровень ее глобализации, транснационализации и вовлеченности в международную торговлю. Раскрыто влияние европейской интеграции Украины на основе результатов Соглашения об ассоциации Украины и ЕС за 2013-2019 г2. в таких аспектах, как: институциональное влияние; поток инвестиций в Украину с ЕС; изменения во внешней торговле Украины и ее регионов; влияние на мальй и средний бизнес; влияние развития экономики ЕС на объемы украинского экспорта в ЕС. Обоснованы направления диверсификации региональной интеграции. Акцентировано на необходимости разработки долгосрочной программы сотрудничества Украины со странами Юго-Восточной Азии с определением приоритетов сотрудничества. Предложены мероприятия по развитию регионального сотрудничества с Китаем, которые заключаются во вступлении Украины в Азиатский банк инфраструктурных проектов и формировании четкого инвестиционного портфолио.

Ключевые слова: глобализачия, регионализация, глобальная регионализация, нащиональная экономика, европейская интеграчия, диверсификация международного сотрудничества.

The essential characteristics of globalization and regionalization and their contradictory relationship are described in the article. The influence of the modern globalization processes and European regionalization on the national economy of Ukraine is analyzed. The globalization and regionalization are a challenge and a chance to increase the competitiveness of the Ukrainian economy. Ukraine need to adapt these processes and take a worthy place in the global economy. Ukraine's interests are the formulate of multi-polar foreign economic policy, the participate in regional blocs with their own zones of influence. The author analyzed the place of Ukraine in the world economy, its level of globalization, transnationalization and involvement into international trade. The impact of European integration of Ukraine on the basis of the Association Agreement between Ukraine and the EU results for the years 2013-2019 is revealed in such aspects as: the institutional impact; the investment flow to Ukraine from the EU; the changes in foreign trade of Ukraine and its regions; the impact on small and medium-sized businesses; the impact of the development of the EU economy on the volume of Ukrainian exports to the EU. The directions of a regional integration diversification are substantiated. In addition to European integration, the development of integration projects with the countries of East Asia and the Asia-Pacific region is promising for Ukraine. Besides, a clear strategy of transregional integration with China is needed. The necessity of developing a long-term program of Ukraine-Asia cooperation with determination of cooperation priorities was emphasized. In the context of the trade globalization, Ukraine should not lose its chance to become a transit country in the East-West direction. The New Silk Road Project and China's interest in diversifying paths offers attractive opportunities for Ukraine. However, Ukraine needs to take a number of measures: to join the Asian Bank for Infrastructure Projects and to formulate clear investment proposals, to develop a portfolio of investment projects that will be beneficial for both parties.

Key words: globalization, regionalization, global regionalization, national economy, European integration, diversification of international cooperation. 
Постановка проблеми. Серед тенденцій сучасного світового розвитку можна виділити процеси глобалізації, з одного боку, і зростання регіоналізації - з іншого. На початку XXI ст. ці процеси наповнилися новими характерними ознаками, що надало можливість виокремити в процесах глобалізації нову стадію, а зростання інтеграційних угрупувань визначити як другу хвилю регіоналізму, або як «новий регіоналізм». Ці відмінності та особливості диктують необхідність розгляду процесів глобалізації та регіоналізації з нових позицій, що дають змогу адекватно оцінити зміни, що відбуваються в глобальній економіці, в інтересах розроблення подальшої стратегії розвитку України. Процеси глобалізації та регіоналізації в силу притаманних їм суперечностей, можливостей та ризиків є полем широких наукових дискусій і формують різноманітні погляди у науковців та практиків.

Аналіз останніх досліджень і публікацій. Питанням глобальних викликів, визначенню ролі та місця України в глобалізаційному світі останнім часом присвячується зростаюча кількість наукових публікацій. Дослідженню проблеми розвитку регіональних та глобальних процесів та їхньому впливу на економіку України присвячено праці О.А. Довгаль, Н.А. Казакової [1], Т.О. Осташко, В.М. Геєця [2], М.П. Бутко [3], Р.В. Тульчинського [4], В.І. Сидорова [5] та ін. У наукових працях глибоко й усебічно розкривається сутність процесів глобалізації та регіоналізації, аналізується їх сучасний стан, розкриваються механізми і напрями розвитку. Втім, в українській науковій літературі $€$ не розкритими особливості розгортання глобалізаційних процесів у сучасних умовах та їхній вплив на перспективи розвитку регіональних об’єднань, зокрема висвітлення потребують перспективи України в розвитку регіональних процесів, тому недостатнє розроблення цих питань визначило вибір проблематики статті.

Мета статті полягає в обгрунтуванні впливу процесів глобалізації та регіоналізації на національну економіку і визначення пріоритетів диверсифікації міжнародного економічного співробітництва України.

Виклад основного матеріалу. Глобалізація та регіоналізація $є$ провідними процесами світового розвитку та «розвиваються як два динамічних процеси, які мають взаємний вплив один на одного» [1].

Глобалізація в іii сучасному варіанті призводить до «переформатування» структури сучасного світу, а в результаті цього - до коригування національних систем державного управління, зміни стратегій економічного, політичного та духовного розвитку, що породжує суцільну взаємозалежність світу, яка і становить основу його функціонування.

На сучасному етапі світового розвитку існують сотні різноманітних тлумачень глобалізації, які є абсолютно суперечливими та взаємовиключними, що пов'язується з відсутністю єдиного розуміння сутності глобалізації та іiі викликів національними спільнотами, їхніх сподівань щодо неї, а також прогнозування наслідків, до яких вона призведе. Аналізуючи поняття «глобалізація», виділяють три підходи до їі визначення: явище або феномен; новий етап інтернаціоналізації; процес. На нашу думку, досить влучною є думка О.А. Довгаль та Н.А. Казакової , які стверджують, що суть процесу глобалізації світової економіки полягає у стрімкому зростанні обсягів і різноманітності світових зв'язків, поширенні процесів, практик і структур від національного простору до глобальних масштабів, у результаті чого посилюється економічна взаємозалежність країн світу, а також формується відносно цілісна економічна система, що практично охоплює територію всієї планети і диктує власні правила гри національним господарствам [1, с. 23]. Уважаємо, що зміна «правил гри» в глобалізованому світі нині змінюється в умовах наростаючої конфронтації Заходу та Сходу й геополітичного та економічного впливу Китаю.

Глобалізація передбачає зростання взаємопов'язаності між різними країнами і досягається не тільки через систему міжнародних відносин, а й через регіоналізацію. Процес регіоналізації може розглядатися як інструмент збереження регіональної ідентичності в умовах глобалізації. Це свідчить про те, що логіка розвитку глобалізації та регіоналізації збігається, різниця полягає у масштабі [5].

Сучасний світовий економічний розвиток характеризується збільшенням процесів регіоналізації, які проявляються у збільшенні ролі певних регіонів, їхнього впливу на інші національні економіки та в результаті спричиняе формування «нового регіоналізму» [3, с. 101]. Р.В. Тульчинський акцентує, що «регіони, набуваючи нових ознак суб'єктів, просувають свої інтереси та пріоритети, стають більш самостійними економічними одиницями, при цьому залишаються відкритими для подальшої європейської інтеграції» [4]. Проте він зазначає, що при цьому новий регіоналізм не повинен нести загроз суверенітету та цілісності державного устрою.

Головним атрибутом нового регіоналізму $\epsilon$ розширений формат і відкритість для інших країн, тобто він об'єднує політичні й економічні сильні боки країн, які прагнуть підняти свою конкурентоспроможність у глобальній економіці. Нові регіональні угрупування істотно відрізняються від попередніх. Вони включають у себе більше країн, у них ширші можливості інтеграції держав, що знаходяться на різних рівнях економічного розвитку.

Підсумовуючи вищевказане, зазначимо, що розвиток світової економіки характеризується збільшенням масштабів регіоналізації (збільшенням автономності регіонів, підвищенням їхньої ролі для національних економік). У результаті цих процесів виник феномен «нового регіоналізму». Зокрема, регіоналізацію розглядають як: 1) зміцнення економічних, соціальних, науково-технічних та інших зв'язків між територіями, державами; 2) виникнення регіональних об'єднань держав.

Регіоналізацію також можна розглядати 3 двох боків: 1) як відповідь на глобалізацію, оскільки регіональні інтереси переважають над глобальними; 2) як 
проміжну ланку на шляху до повної глобалізації (створення регіональних блоків). Глобалізація, на думку одних учених, органічно пов'язана 3 процесами регіоналізації [6]. Створення регіональних організацій, число яких постійно зростає, - це і свого роду сходинка глобалізації. Але існують й протилежні погляди, зокрема вчені стверджують, що розширення регіональної співпраці стало відповіддю на процеси глобалізації, оскільки багато країн розглядають інтеграційні союзи як можливість уникнути негативних процесів, які пов'язані з глобалізацією. Наприклад, сучасна світова господарська система рухається в напрямі багатополярності, оскільки утворюється новий глобальний процес - істернізація (посилення впливу країн Сходу).

Уважаємо, що на сучасному етапі розвитку світового господарства глобалізація знаходиться на новому щаблі розвитку, який можна визначити як глобальну регіоналізацію, важливою проблемою якої є визначення тенденцій регіонального процесоутворення в контексті багатофакторної глобалізації, оскільки вона передбачає зміни у розвитку регіонів, їх інтеграцію та взаємодію. Тому основне протиріччя між процесами глобалізації та регіоналізації пов'язане з розвитком регіональних блоків, метою створення яких спочатку було отримання прибутків у результаті співпраці країн - учасниць блоків та сприяння загальному розвитку глобалізації. Проте коли негативні наслідки глобалізації стали відчуватися більшою мірою, то однією із цілей регіональних блоків стало співробітництво щодо зниження іï негативного впливу.

Таким чином, сучасний глобальний регіоналізм передусім можна кваліфікувати як початок історично нової, вищої фази розвитку глобальної економіки. У зв'язку із цим найважливішим складником парадигми регіонального пізнання стає вивчення регіону як елемента багаторівневої системи конкурентної взаємодії в мережі регіонів. Сьогодні найбільш потужними є три регіональних об'єднання, які уособлюють «нову геометрію світу» - геометрію тріади: СС, НАФТА і АТЕС, на їхню частку припадає $79 \%$ світового ВВП (відповідно 24\%, 26\% і 29\%); $75 \%$ світового експорту $(43 \%, 17 \%$ і $25 \%) ; 74 \%$ інвестицій $(19 \%, 19 \%$ і 36\%) і 46\% населення планети (7\%, 5\%, і 34\%) [6]. Найбільш «просунутим» інтеграційним угрупованням у світі є Європейський Союз, який у своєму розвитку за півстоліття пройшов усі етапи інтеграції та із зони вільної торгівлі перетворився на економічний і валютний союз, а євро стало найсильнішою валютою в світі.

Розвиток української економіки відбувається під впливом глобалізації та регіоналізації, тому спочатку проаналізуємо роль нашої країни в глобальній економіці. Місце України в умовах глобалізації можна підтвердити на основі аналізу країни у світовому господарстві на основі таких показників, як рівень глобалізації, транснаціоналізації та залученості у міжнародну торгівлю. Якщо в докризовий період частка України у світовому виробництві зростала прискореними темпами, то останніми роками економічна динаміка країни істотно поступається світовій, унаслідок чого частка країни у світовій економіці помітно зменшилася, що відображено в табл. 1 [7].

За показником частки країни у світовому ВВП Україна у період 2011-2016 pр. дедалі більше втрачала свою «Помітність» у глобальній економіці. Проте у 2018 р. повернулася до рівня 2008 р. (0,29\% у структурі світового ВВП).

Згідно з Індексом глобалізації [8], який розраховує Швейцарський економічний інститут (KOF), 2017 р. Україна посідала 45-е місце в рейтингу серед 193 країн. Із метою оцінки глобалізаційних процесів в Україні було проаналізовано Індекс глобальної конкурентоспроможності [9]. Наша країна у 2017-2018 рр. зайняла 81-е місце серед 137 країн світу. Найбільше відставання спостерігалося за показниками «інституції», «інфраструктура», «технологічна готовність», «відповідність бізнесу сучасним вимогам», «інновації».

Місце України у світовій економіці, $\%$ у світовому ВВП

\begin{tabular}{|c|c|}
\hline Роки & Частка України у світовому ВВП, \% \\
\hline 2000 & 0,10 \\
\hline 2008 & 0,29 \\
\hline 2011 & 0,23 \\
\hline 2014 & 0,17 \\
\hline 2016 & 0,22 \\
\hline 2018 & 0,29 \\
\hline
\end{tabular}

Джерело: складено за [7]

Аналіз тенденцій транснаціоналізації як об'єктивного процесу посилення світової інтеграції в результаті нарощування обсягів міжнародних операцій ТНК свідчить, що індекс корпоративної транснаціоналізації України становить 10\%. Індекс є більшим, аніж у США (7,1\%), Японії (4,2\%), Італії (6,3\%), з огляду на високий рівень експортоорієнтованості, імпортозалежності базових галузей економіки України та офшорне інвестування [10].

Також слід констатувати, що, попри високий рівень відкритості, Україна значно не є залученою до глобальних торговельних потоків. Так, згідно з глобальним Індексом залучення країн світу до міжнародної торгівлі (останні дані 2016 р.), Україна посідала 95-ту позицію серед 136 оцінених країн [11]. Погіршення рейтингових позицій України відбулося за всіма основними складниками Індексу. Причому найбільше наша країна втратила за показником, який характеризує діловий клімат у країні, посунувшись зі 106-го на 125-е місце. Найбільш проблемними чинниками для імпорту є корупція на кордоні, а для експорту - визначення потенційних ринків та покупців.

У контексті впливу регіоналізації на економіку України розглянемо конкретні результати Угоди про асоціацію України та ЄС, яка була підписана у 2014 р. i стала реальним кроком для забезпечення євроінте- 
граційних процесів. Вплив європейської регіоналізації на національну економіку за період 2013-2019 рр. проявляється в таких аспектах [3; 12-15]:

1) інституційний вплив (на 2018 р. Угоду виконано на $52 \%$ );

2) прямі іноземні інвестиції в Україну з СС (Кіпр, Нiдерланди, Велика Британія є основними інвесторами);

3) зміни у зовнішній торгівлі України та іï регіонів. За підсумками 2019 р. найбільшим торговельним партнером України стали СС та Китай. Згідно з даними Індексу євроінтеграційного поступу регіонів України у 2016 р. карта євроінтеграційного економічного поступу набула більш рівномірного вигляду з акцентом на західно-північні локації. Значний ступінь зближення з економікою ЄС показали 15 областей, тоді як у 2014 р. їх було лише сім;

4) вплив на малий та середній бізнес. Малий та середній бізнес за індексом інтернаціоналізації має невисокий рівень виходу на міжнародні ринки. При цьому більшість країн Свропи показала середній та нижче середнього результати. Україна ж отримала найнижчий показник - 0,45 балів;

5) вплив розвитку економіки СС на обсяги вітчизняного експорту до ЄС. Між темпами зростання українського експорту до СС і темпами зростання промислового виробництва 27 країн СС у 2005-2015 pр. існує тісний взаємозв'язок (коефіцієнт парної кореляції 0,71). Уповільнення темпів зростання промислового виробництва у країнах СС на $1 \%$ викликає зменшення темпів приросту експорту товарів 3 України до $\mathrm{CC}$ на $2,7 \%$.

Але розташування України на межі двох великих цивілізаційних просторів - європейського та азійського - було й $є$ одним із визначальних чинників іiї політичного та економічного розвитку. Вже сьогодні ні для кого не $є$ новиною, що XXI ст. - це нова епоха для Східної Азії та Азійсько-Тихоокеанського регіону (АТР), які претендують на місце лідируючого мегарегіону у світовій економіці, який забезпечує процеси взаємодії та взаємозалежності у світових процесах. Тому на часі для України постає питання не лише європейської інтеграції, а й стратегічні питання диверсифікації регіонального співробітництва, розроблення довготермінової програми співробітництва України з країнами Південно-Східної Азії з визначенням пріоритетів співробітництва та конкретних заходів сприяло б збалан- суванню торговельно-економічного співробітництва між ними та значному підвищенню обсягів торгівлі.

В умовах глобалізації торгівлі Україна повинна не втратити свій шанс стати транзитною державою в напрямку «Схід - Захід». У цьому контексті Україна має реальні перспективи у відношенні посилення своєї ролі як транзитної держави. Цьому сприяють об'єктивні чинники - геополітичне положення та наявність потужного транспортного комплексу.

Зокрема, Великий шовковий шлях та зацікавленість Китаю в диверсифікації шляхів відкриває для України привабливі можливості [16]. На нашу думку, Україні задля масштабного входження в «Економічний пояс» та перспективного розвитку регіонального співробітництва з Китаєм необхідно вжити низку заходів: вступити до Азіатського банку інфраструктурних проєктів, оскільки ця міжнародна фінансова організація є основним інвестором в інфраструктурні проєкти «Одного поясу, одного шляху»; сформувати чіткі інвестиційні пропозиції, розробити портфоліо інвестиційних проєктів, які будуть вигідні для обох сторін.

Висновки. Таким чином, регіоналізація та глобалізація - різноспрямовані паралельні процеси розвитку сучасних міжнародних відносин. Обидва ці тренди існують в сучасній геополітиці й світовій економіці, що зумовлює їх урахування під час визначення зваженої внутрішньої і зовнішньої економічної політики держав.

Для України глобалізація та регіоналізація є, з одного боку, викликом, а з іншого - шансом підвищити конкурентоспроможність національної економіки. В обох випадках Україна повинна адаптуватися до цих процесів і зайняти гідне місце в глобальній економіці. Інтереси України полягають у формуванні багатополюсної зовнішньоекономічної політики, участі в регіональних блоках зі своїми зонами впливу.

Виходячи з вищенаведеного, вважаємо, що Україні необхідно розширювати регіональну співпрацю, що значною мірою стало відповіддю на процеси глобалізації. Україна розглядає інтеграційні союзи як спосіб уникнути негативних процесів, пов'язаних із глобалізацією, й як найбільш ефективний шлях підвищення конкурентоспроможності. Окрім європейської інтеграції, перспективними для розвитку є інтеграційні проєкти з країнами Східної Азії й Азійсько-Тихоокеанського регіону, зокрема необхідна чітка стратегія трансрегіональної інтеграції з Китаєм.

\section{Список літератури:}

1. Глобалізація та регіоналізація як вектори розвитку міжнародних економічних відносин : колективна монографія / за ред. О.А. Довгаль, Н.А. Казакової. Харків : ХНУ імені В.Н. Каразіна, 2018. 540 с.

2. Імплементація Угоди про асоціацію між Україною та ЄС: економічні виклики та нові можливості : наукова доповідь / за ред. акад. НАН України В.М. Геєця та чл.-кор. НААН України Т.О. Осташко. Київ, 2016. $184 \mathrm{c}$.

3. Бутко М.П. Архітектоніка конкурентоспроможності регіонів України в контексті євроінтеграції: монографія. Київ : АМУ, 2016. 452 с.

4. Тульчинський Р.В. Категоріально-понятійний апарат становлення нового регіоналізму. Економічний аналіз. 2017. T. 27. № 4. С. 111-117.

5. Сидоров В.И. Влияние глобализации на синхронность протекания экономических процессов в рамках мировой экономики. Бізнес Інформ. 2017. № 3. С. 16-20. 
6. Бабурина О.Н. Регионализация и глобализация: к проблеме взаимосвязи URL : http://www.m-economy.ru/art. php?nArtId=2161 (дата звернення: 20.02.2020).

7. World Economic Outlook Reports (різні випуски). URL : http://www.imf.org/external/ns/cs.aspx?id=29 (дата звернення: 25.02.2020).

8. KOF Index of Globalization. URL : http://globalization.kof.ethz.ch. (дата звернення: 25.02.2020).

9. The Global Competitiveness Report 2017-2018 / World Economic Forum. 2017. URL : http://www.weforum.org (дата звернення: 25.02.2020).

10. Келару І.О. Транснаціоналізація і конкурентоспроможний розвиток економіки України : автореф. дис. ... канд. екон. наук : 08.00.02 ; ДВНЗ «Київ. нац. екон. ун-т ім. В. Гетьмана». Київ, 2014. 21 с.

11. Ukraine. Enabling Trade Index 2016. URL : http://reports.weforum.org/global-enabling-trade-report-2016/ economy-profiles/\#еconomy=UKR (дата звернення: 25.02.2020).

12. Звітпровиконання УгодипроасоціаціюміжУкраїноютаЄвропейськимСоюзом.URL:https://www.kmu.gov.ua/ storage/app/sites/1/55-GOEEI/AA_report_UA.pdf (дата звернення: 06.03.2020).

13. Географічна структура зовнішньої торгівлі товарами у 2018 році. Офіційний сайт Державної служби статистики України. URL : http://www.ukrstat.gov.ua/operativ/operativ2018/zd/ztt/ztt_u/ztt1218_u.htm (дата звернення: 07.03.2020).

14. Індекс Євроінтеграційного економічного поступу в Україні 2014- 2016: три роки на шляху до єдиного європейського економічного простору / упоряд. М. Корявець. Чернігів : Поліський фонд міжнародних та регіональних досліджень, 2017-2018. 49 c. URL : http://fmd.kh.ua/wp-content/uploads/2018/02/IEEP-REPORT-2018_final. pdf (дата звернення: 09.03.2020).

15. Офіційний сайт EasyBusiness. URL : http://www.easybusiness.in.ua/uk/\%D0\%B3\%D0\%BE\%D0\%BB\%D0\% $\mathrm{BE} \% \mathrm{D} 0 \% \mathrm{~B} 2 \% \mathrm{D} 0 \% \mathrm{BD} \% \mathrm{D} 0 \% \mathrm{~B} 0$ (дата звернення: 12.03.2020).

16. Лисенко В. Новий шовковий шлях: Яке місце України? 2019. URL : https://zik.ua/news/2019/09/25/novyy_ shovkovyy_shlyah_chy_mogla_b_ukraina_pryiednatysya_do_nogo_1653943 (дата звернення: 03.04.2020).

\section{References:}

1. Dovhal O. A., Kazakova N. A. (2018). Hlobalizatsiia ta rehionalizatsiia yak vektory rozvytku mizhnarodnykh ekonomichnykh vidnosyn [Globalization and regionalization as vectors of international economic relations development]. Kharkiv : KhNU imeni V. N. Karazina (in Ukrainian).

2. Heiets V.M., Ostashko T.O. (2016). Implementatsiia Uhody pro asotsiatsiiu mizh Ukrainoiu ta YeS: ekonomichni vyklyky ta novi mozhlyvosti [Implementation of the EU-Ukraine Association Agreement: economic challenges and new opportunities]. Kyiv: DU «In-t ekon. ta prohnozuv. NAN Ukrainy» (in Ukrainian).

3. Butko M. P. (2016). Arkhitektonika konkurentospromozhnosti rehioniv Ukrainy v konteksti yevrointehratsii [Architectonics of Ukrainian regions's competitiveness amid European integration]. Kyiv : AMU (in Ukrainian).

4. Tulchynskyi R. V. (2017). Katehorialno-poniatiinyi aparat stanovlennia novoho rehionalizmu [The categorical-conceptual apparatus of the new regionalism formation]. Ekonomichnyi analiz: zb. nauk. prats [Economic analysis]. Ternopil: Vydavnycho-polihrafichnyi tsentr Ternopilskoho natsionalnoho ekonomichnoho universytetu «Ekonomichna dumka», vol. 27/4, pp. 111-117.

5. Sidorov V. I. (2017). Vlijanie globalizacii na sinhronnost protekanija jekonomicheskih processov v ramkah mirovoj jekonomiki [Influence of globalization on the synchronism of economic processes within the global economy]. Biznes Inform [Business Inform]. vol. 3, pp. $16-20$.

6. Baburina O. N. Regionalizacija i globalizacija: k probleme vzaimosvjazi [Regionalization and globalization: the problem of the relationship]. Available at: http://www.m-economy.ru/art.php?nArtId=2161 (accessed 20 February 2020) (in Russian).

7. World Economic Outlook Reports. Available at: http://www.imf.org/external/ns/cs.aspx?id=29. (accessed 25 February 2020) (in English).

8. KOF Index of Globalization. Available at: http://globalization.kof.ethz.ch. (accessed 25 February 2020) (in English).

9. The Global Competitiveness Report 2017-2018. World Economic Forum. 2017. Available at: http://www.weforum. org (accessed 25 February 2020) (in English)

10. Kelaru I. O. (2014). Transnatsionalizatsiia i konkurentospromozhnyi rozvytok ekonomiky Ukrainy: avtoref. dys. ... kand. ekon. nauk [Transnationalization and competitive development of the Ukrainian economy: abstract. diss. ... Cand. econom. Sciences], Kyiv : DVNZ «Kyiv. nats. ekon. un-t im. V. Hetmana».

11. Ukraine. Enabling Trade Index 2016. Available at: http://reports.weforum.org/global-enabling-trade-report-2016/ economy-profiles/\#economy=UKR (accessed 25 February 2020) (in English).

12. Zvit pro vykonannia uhody pro asotsiatsiiu mizh Ukrainoiu ta Yevropeiskym Soiuzom [Report on the implementation of the Association Agreement between Ukraine and the European Union]. Available at: https://www.kmu.gov.ua/ storage/app/sites/1/55-GOEEI/AA_report_UA.pdf (accessed 06 March 2020) (in Ukrainian).

13. Heohrafichna struktura zovnishno $\bar{i}$ torhivli tovaramy u 2018 rotsi [The geographical structure of foreign trade in goods in 2018]. Ofitsiinyi sait Derzhavnoi sluzhby statystyky Ukrainy [Official site of the State Statistics Service of Ukraine]. Available at: http://www.ukrstat.gov.ua/operativ/operativ2018/zd/ztt/ztt_u/ztt1218_u.htm (accessed 07 March 2020) (in Ukrainian). 
14. Koriavets M. (2018). Indeks Yevrointehratsiinoho Ekonomichnoho Postupu v Ukraini 2014 - 2016: try roky na shliakhu do yedynoho yevropeiskoho ekonomichnoho prostoru [Index of European Integration Economic Progress in Ukraine 2014 - 2016: three years on the way to a single European economic space] Chernihiv: Poliskyi fond mizhnarodnykh ta rehionalnykh doslidzhen. Available at: http://fmd.kh.ua/wp-content/uploads/2018/02/IEEP-REPORT-2018_final. pdf (accessed 09 March 2020) (in Ukrainian).

15. Ofitsiinyi sait «EasyBusiness» [EasyBusiness official site]. Available at: http://www.easybusiness.in.ua/uk/\% D0\%B3\%D0\%BE\%D0\%BB\%D0\%BE\%D0\%B2\%D0\%BD\%D0\%B0 (accessed 12 March 2020) (in Ukrainian).

16. Lysenko V. (2019) Novyi shovkovyi shliakh: Yake mistse Ukrainy? [The New Silk Road: What is the Place of Ukraine?]. Available at: https://zik.ua/news/2019/09/25/novyy_shovkovyy_shlyah_chy_mogla_b_ukraina_pryiednatysya_do_nogo_1653943 (accessed 3 April 2020) (in Ukrainian). 